\title{
Integrating flood mitigation, sediment management and habitat enhancement on coastal rivers of British Columbia
}

\author{
D. McLean ${ }^{1}$, V. Galay ${ }^{1}$, B. Wright ${ }^{2} \&$ W. Fleenor ${ }^{3}$ \\ ${ }^{1}$ Northwest Hydraulic Consultants Ltd, North Vancouver, BC, Canada \\ ${ }^{2}$ Nova Pacific Consultants, Vancouver, BC, Canada \\ ${ }^{3}$ Current Environmental, Courtenay, BC, Canada
}

\begin{abstract}
This paper describes the challenges of reconciling flood mitigation, sediment management and aquatic habitat preservation on two rivers in British Columbia: the Vedder River in the lower Fraser Valley and the Cowichan River on Vancouver Island. Both rivers were channelized and modified greatly at the turn of the last century and were diked to protect rapidly growing communities against flooding. Both support important salmon stocks but have experienced habitat loss due to past flood control works. The lower reaches of the rivers are alluvial fans and are subject to gravel aggradation and avulsion hazards. River management on these systems involves mitigating flood risks on stream channels that are subject to aggradation and sediment deposition while preserving or enhancing aquatic habitat.
\end{abstract}

Keywords: floods, alluvial fan, sedimentation, habitat, restoration.

\section{Introduction}

Southwest British Columbia is characterized by steep, rugged mountains of the Coast Range and deep, forested river valleys that were shaped by the Pleistocene glaciation. During Holocene times the streams have incised through post-glacial outwash and transport large quantities of gravel bedload, which eventually deposits on the alluvial fans and coastal floodplains where most human settlement has concentrated. Prior to European contact, First Nations developed a thriving culture based on the immense salmon resources of the region. European settlement commenced in the 1840s. Since then, efforts were made to control 
floods and river erosion by channelizing and diverting the rivers and by constructing flood dikes. Recently, the need for integrated flood management has been emphasized, which involves applying a mix of non-structural and structural flood mitigation methods. The overall goal is to reduce flood risks to communities on the floodplain while protecting aquatic and riparian habitat and maintaining the cultural values of the rivers. Implementing integrated flood management on artificially confined, aggrading streams is particularly challenging since conflicts will arise between the need to periodically remove sediment and the need to protect or enhance aquatic habitat.

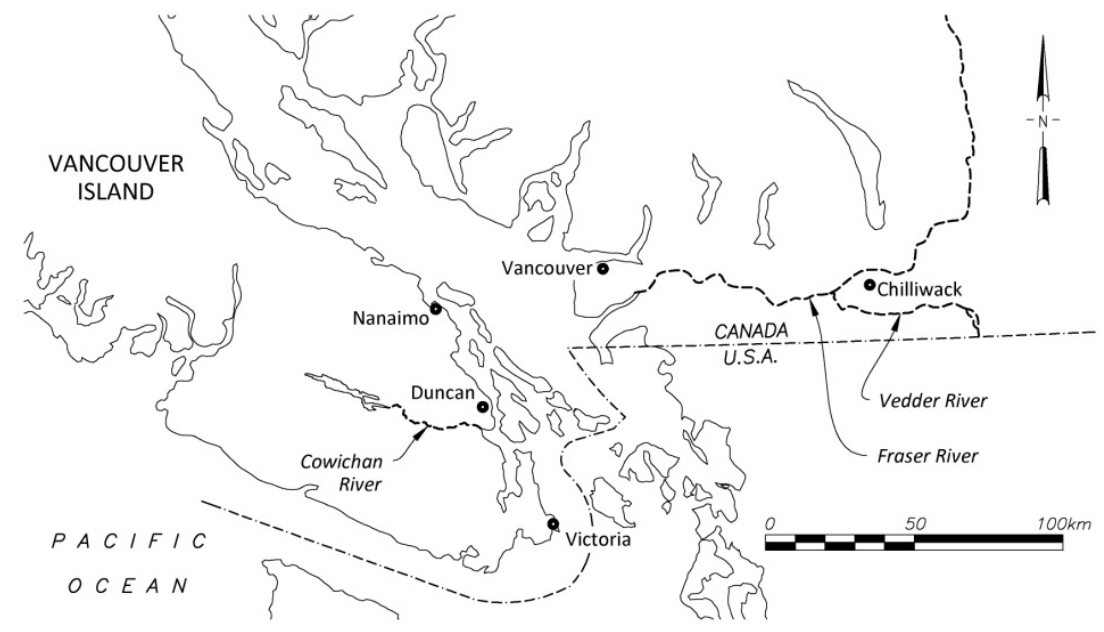

Figure 1: $\quad$ Site location.

This paper illustrates some of the challenges of river management in coastal British Columbia using case histories from the Vedder River in the lower Fraser Valley near Chilliwack and the Cowichan River on southeastern Vancouver Island and makes comparisons with the situation on the much larger Lower Fraser River (Figure 1). Table 1 summarizes some key features of these rivers.

Table 1: $\quad$ Comparison of river basins.

\begin{tabular}{|l|c|c|c|c|}
\hline Basin Features & Unit & Vedder & Cowichan & Fraser \\
\hline Drainage Area & $\mathrm{km}^{2}$ & 1230 & 826 & 230,000 \\
\hline Mean Daily Flow & $\mathrm{m}^{3} \mathrm{~s}^{-1}$ & 66.8 & 52.7 & 3,000 \\
\hline 200 Year Flood & $\mathrm{m}^{3} \mathrm{~s}^{-1}$ & 1270 & 700 & 17,000 \\
\hline Suspended Load & Tonne yr & 130,000 & 35,000 & $18,000,000$ \\
\hline Bedload & Tonne yr & 75,000 & 25,000 & 400,000 \\
\hline Active Channel Width & $\mathrm{m}$ & 130 & 40 & 900 \\
\hline
\end{tabular}




\section{Chilliwack-Vedder River}

\subsection{Setting}

The Chilliwack River flows through the Cascade Mountains until reaching a narrow gorge near Vedder Crossing where it spills onto the Fraser Lowlands. The lower river is actively building an alluvial fan by depositing its gravel and sand bedload. Downstream of Vedder Crossing, it is called Vedder River after a major avulsion in the $19^{\text {th }}$ century turned the river down Vedder Creek and into Sumas Lake.

\subsection{Flood control}

A major reclamation project in the 1920s drained Sumas Lake and channelized the lower river into the Vedder Canal. Since then, Sumas Lake and the surrounding wetlands were transformed into farmland. During the 1960s the dikes were extended upstream to Vedder Crossing, although significant sediment deposition and flooding was experienced upstream from the canal.

Past attempts at flood control produced strong criticism from environmental groups and fisheries agencies due to concerns about destruction of spawning and rearing areas for salmon and steelhead trout. The Vedder River supports important commercial pink and chum salmon runs as well as sport fishery for coho and steelhead.

In 1983 the Vedder River Management Plan proposed a system of flood control works including setback dikes on the floodplain, bank protection along both sides of the main channel to maintain a stable alignment, a series of groynes to protect the setback dikes and a program of ongoing sediment removal (Figure 2).

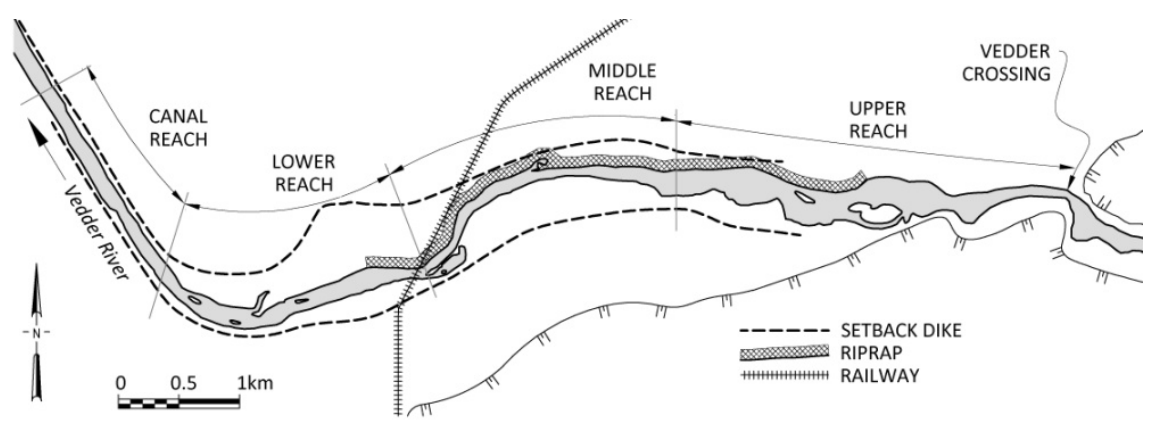

Figure 2: $\quad$ Vedder River management area.

\subsection{Sediment management}

Estimates of gravel bedload transport rates have been made using direct bedload measurements as well as by using sediment budget techniques (Martin and Church [1], Ham and Church [2]). The long-term average annual gravel inflow 
rate at Vedder Crossing ranges from 50,000 to $75,000 \mathrm{~m}^{3}$. During large floods the gravel transport rate exceeds $250,000 \mathrm{~m}^{3}$.

The transport capacity decreases downstream from Vedder Crossing in response to the decrease in slope. The zone of greatest deposition occurs near the head of the Vedder Canal - this is also the location of a dramatic change in river/canal slope (Figure 3). Over time this aggradation has led to a downstream extension of the gravel reach. The water surface slope of the river reach is about twice as steep as that of the canal reach.

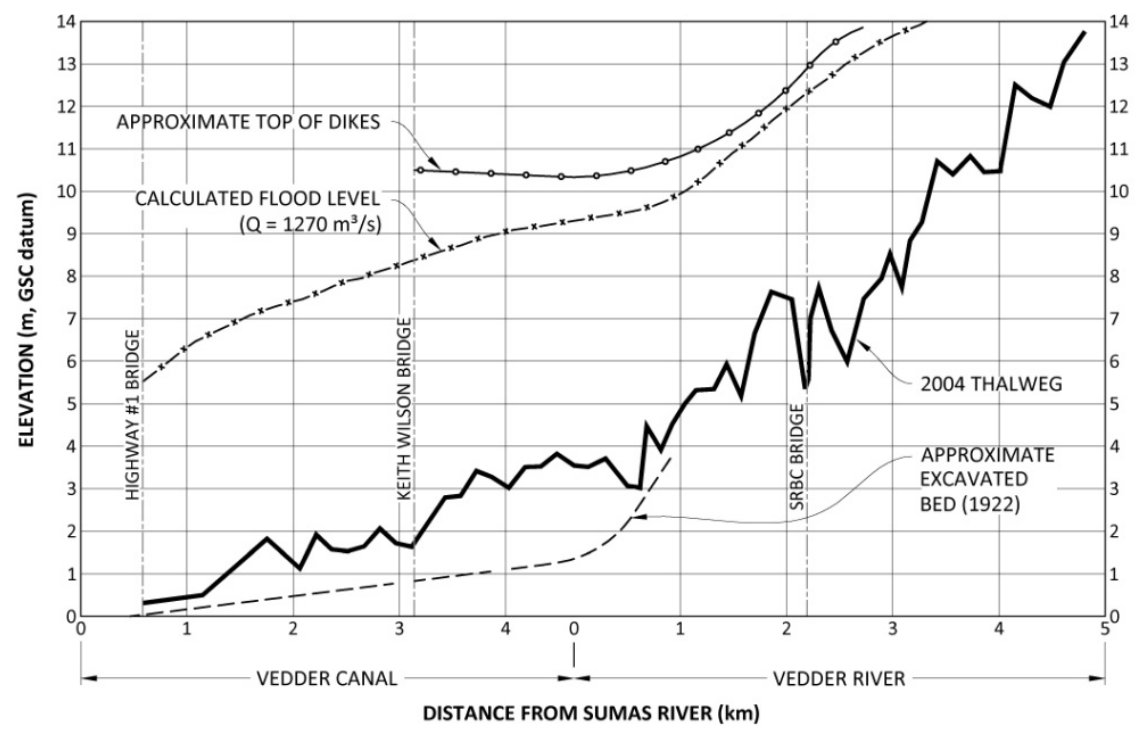

Figure 3: Longitudinal profile of Vedder River.

\subsection{Review of gravel excavation programs}

Maintaining a stable 200 year flood profile has required annual gravel removals of about 75,000 m $\mathrm{yr}^{-1}$ since 1983 (Bergmann [3]). Several distinctly different gravel removal strategies have been tried over the years. Commencing in 1994, a program of excavating deep pits, as opposed to scalping which had been the previous norm, was commenced. This program has been characterized by a high level of effort to meld the often conflicting goals of retaining fish habitat capacity while meeting flood control objectives.

Figure 4 illustrates an example of an excavation through a series of alternate bars. Both bars were excavated below low water levels and side openings were established near the upstream and downstream ends of the excavations. The aim was to develop a separate low flow meandering channel for fish as well as to provide space to trap mobile gravel to limit further bed aggradation. However, the new channels and pits filled rapidly with gravel and the bars were refilled to their pre-excavation geometries. Originally, fisheries biologists had hoped that the excavated meandering flow pattern would persist. This did not happen. 
Examination of sequential air photos showed an early onset of headcutting at the upstream opening of the excavated pit. This headcutting progressed upstream and captured the mobile gravel from the deep channel when the winter peak flows occurred. This means that the moving gravel within the river did not proceed downstream.
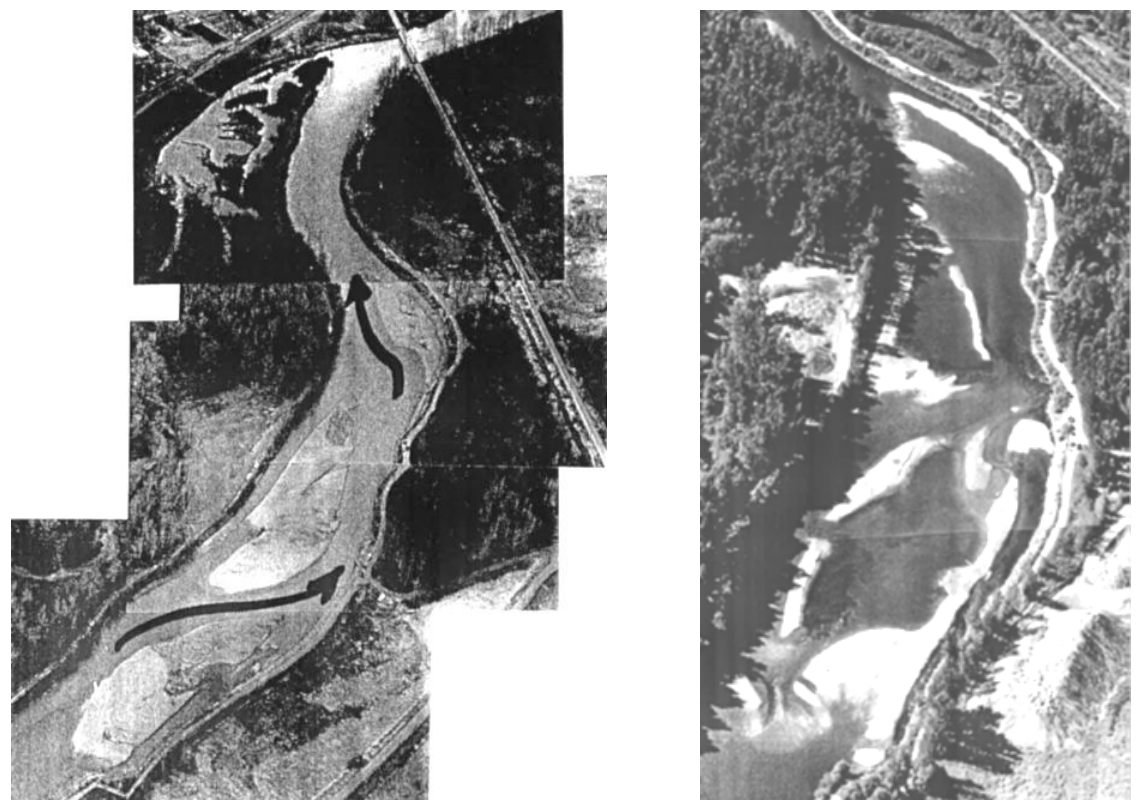

Figure 4: Gravel removal through alternate bars.

Another example was in the braided reach (Reach No. 1) where a series of deep pits was excavated. The purpose of the excavation was two-fold: 1) to trap gravel thereby reducing volumes moving farther downstream and 2) to remove a silt-clay plugged surface which reduces the quality of fish habitat and may also reduce the charging of a key aquifer for domestic and agricultural uses. The clogging of voids in gravel deposits by fine silt and clay reduces the survival of eggs within the various redds along the river bed. In 1995, landslides at the headwaters of the Chilliwack River had deposited a relatively thick layer of "rubbery" silt-clay on the bed of the Vedder River below Vedder Crossing. After review of Reach No. 1 it was decided that the construction of a series of pits near the left river bank would clear a reasonable length of "plugged" river bed; however, in order to do so, the pits would have to be relatively deep and convey a major portion of the flowing river. A series of four separate pits, relatively close to each other, was excavated during the summer of 1996 (Figure 5).

The four pits were excavated by deep scrapers and excavators along a gradual alignment near the south river bank. This new channel would have riffles and pools and no fine sediments. The excavation of the series of pits resulted in the removal of almost $200,000 \mathrm{~m}^{3}$ of gravel. A headcut channel was excavated the 
upper end of the first pit so that new gravel would fill the pits and the silt-clay would ultimately be washed through the system. Subsequently, a sequence of winter flows in 1996-97 refilled the pits and provided more wetted area, pools and riffles for fish habitat.

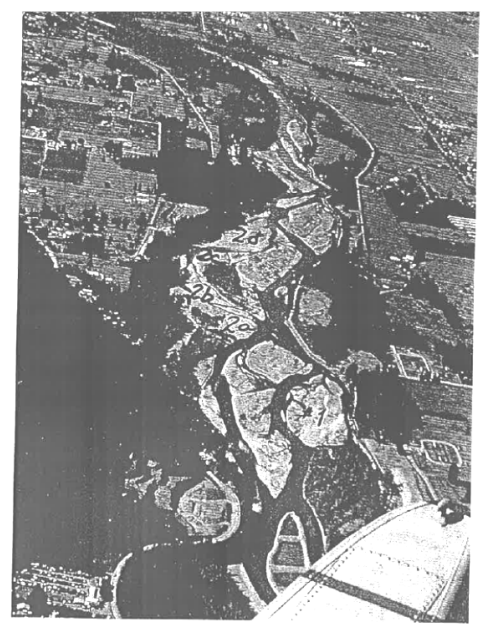

Figure 5: $\quad$ Excavation in braided reach.

In 2008, nine removal sites were completed for a total removal volume of $106,000 \mathrm{~m}^{3}$. An environmental assessment was undertaken to determine fish habitat changes and other impacts related to the sediment removal program (Nova Pacific [4]).

Habitat assessment was undertaken at the time of the excavations and again approximately one year later to determine whether the excavations had altered habitat types in their vicinity. Aerial photography forms the basis for habitat mapping and allows comparison from year to year. The maps were divided into polygons that were assigned to 16 different habitat types. Individual polygons were rated and summarized at the excavation level and at the reach level. The assessment showed four of the nine sites were found to be positive from the habitat perspective, three were found to be neutral and two were found to be negative. Overall, habitat impacts were small and difficult to distinguish from normal river changes.

\subsection{Assessment of sediment management program}

The flood control dikes have withstood large flood events in 2003 and 2006, having return periods of between 50 and 100 years without experiencing significant damage. Furthermore, the habitat values of the system have been maintained over the last 30 years. The experience has demonstrated that the program can successfully balance the needs for managing sediment and maintaining aquatic habitat. 


\section{Cowichan river}

\subsection{Physical setting}

The Cowichan River is frequently controlled by bedrock through its upper course. The stream exits from a narrow canyon just upstream of the City of Duncan and then flows $7 \mathrm{~km}$ across the Nanaimo Lowland until reaching Cowichan Bay. This lower reach has experienced periodic flooding, channel shifting and gravel bedload deposition.

Based on the abundance and variety of salmonid species, the Cowichan River is recognized as one of the most important and productive fish bearing rivers on Vancouver Island. Anadromous fish species present in the study area include a fall run of chinook salmon (Oncorhynchus tshawytscha), coho salmon (O. kisutch), chum salmon (O. keta) and winter run steelhead (O. mykiss). Fish habitat values are high or very high due to the extensive system of accessible, low gradient channels that are interconnected with sloughs and backwatered ponds.

\subsection{History of flood control efforts}

The earliest maps in 1867 show the river flowed across the lowlands in a network of channels. By 1946 the two southern branches were closed. During construction of the Trans-Canada Highway Bridge, the main channel was shifted north to its present location and the former channel was cut off and abandoned. A system of dikes was constructed along portions of the Cowichan River starting in the 1970s (Figure 6).

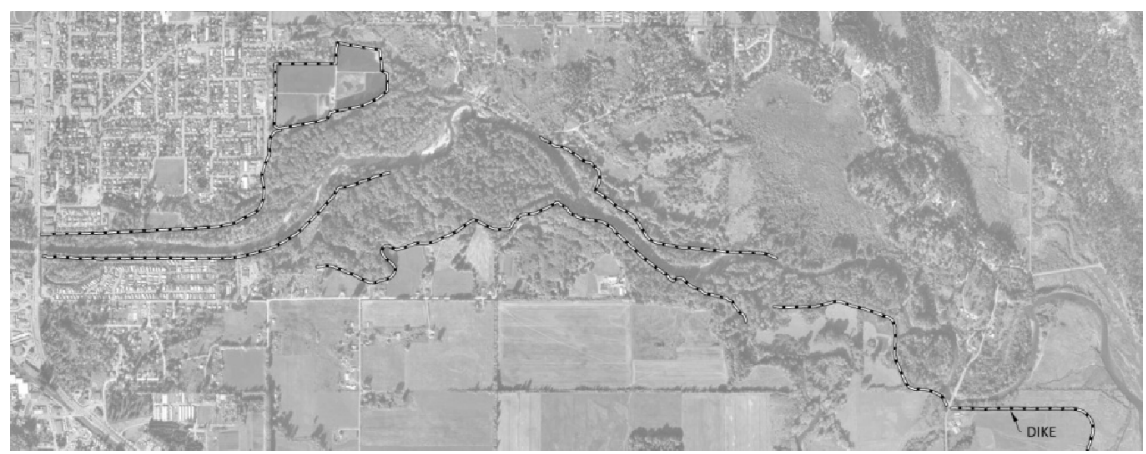

Figure 6: Channelization on Cowichan River.

Persistent channel instability and sediment deposition problems were experienced in response to these channelization efforts. The City of Duncan has experienced flooding 14 times over a period of 40 years (approximately once every four years). In 2009, the City of Duncan was inundated by a flood with a discharge having a return period of only 7 years. Although the flood discharge was not exceptionally large, the peak flood level exceeded the long time high 
water mark set in 1961 by $0.2 \mathrm{~m}$. The 200 year flood water level was revised three times since 1981, an average of $+0.05 \mathrm{~m} /$ year (Figure 7 ).

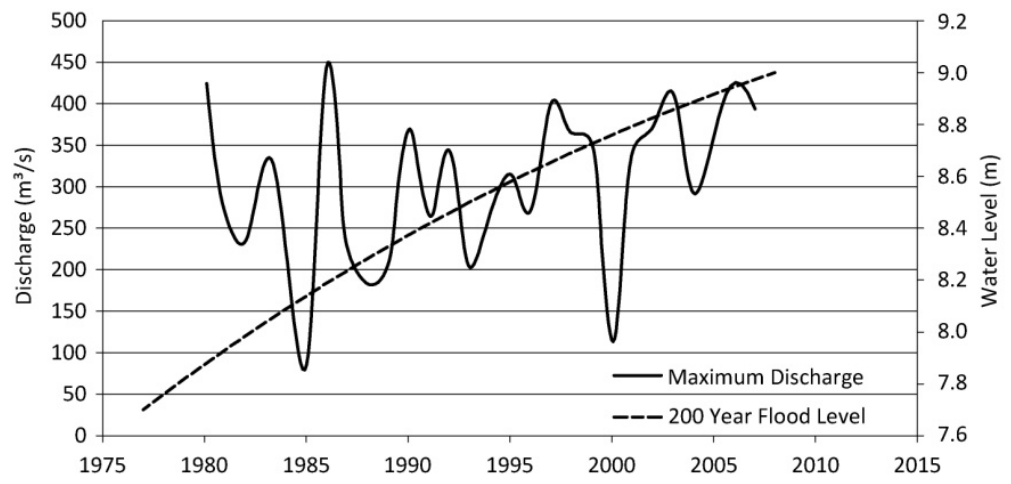

Figure 7: Maximum discharges and estimated 200 year flood level near Duncan.

The rise in the estimated 200 year flood level is not due to changes in discharge, but has been related to factors such as sedimentation, channel alignment shifts and confinement effects from downstream dike construction.

\subsection{Sedimentation}

A sediment budget assessment indicated approximately $500,000 \mathrm{~m}^{3}$ of gravel was deposited in a $3 \mathrm{~km}$ reach of the river between 1977 and 2008. Recent surveys indicate $25,000 \mathrm{~m}^{3}$ of gravel was deposited on the surface of the visible channel bars between 2008 and 2010. Actual year to year rates are highly variable, responding to fluctuations in flood magnitude and gravel recruitment.

Gravel deposition has not occurred uniformly; it is transported through narrow channelized reaches and deposits in wider unconfined sections where the gradient is reduced (Figure 8). Repeat surveys show aggradation of up to $2.5 \mathrm{~m}$ over the last 15 years in these deposition zones. This localized deposition is a major factor that controls channel instability and bank erosion (Figure 9). Bank erosion is frequently associated with log jams and debris deposition. Woody debris ranges from individual logs found on channel bars to large jams that span the entire channel. The location of jams is closely associated with the locations of channel bars and sediment deposition. Log jams can temporarily raise water levels by $0.5 \mathrm{~m}$ or more during high flows. As a result, a moderate flood discharge (10 to 20 year event) combined with a log jam can produce a higher water level than a 200 year discharge event that occurs without log jams. Sediment deposition has required updating floodplain maps and raising dikes. 


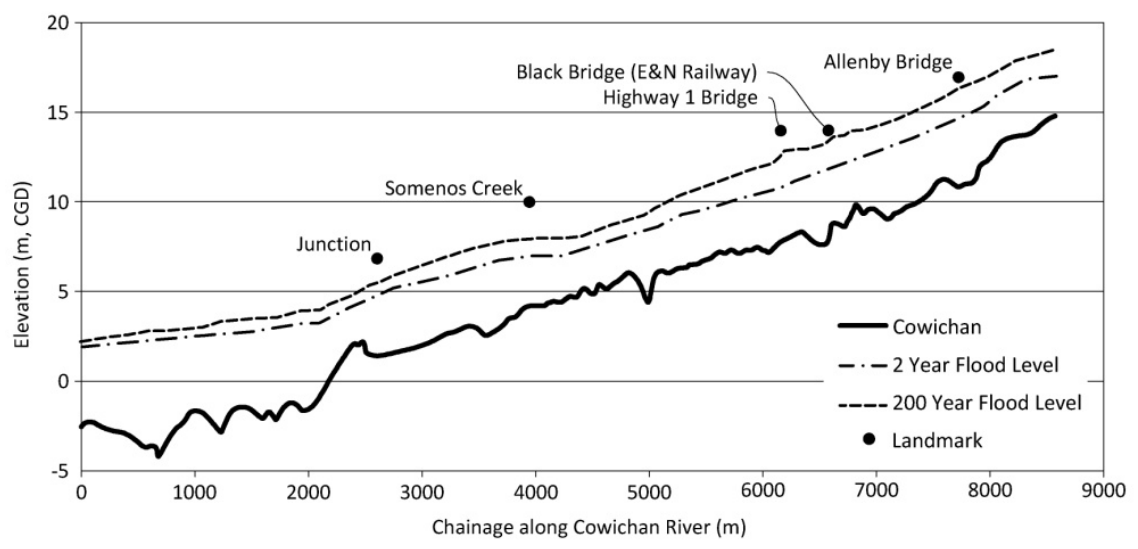

Figure 8: $\quad$ Longitudinal profile of Cowichan River.
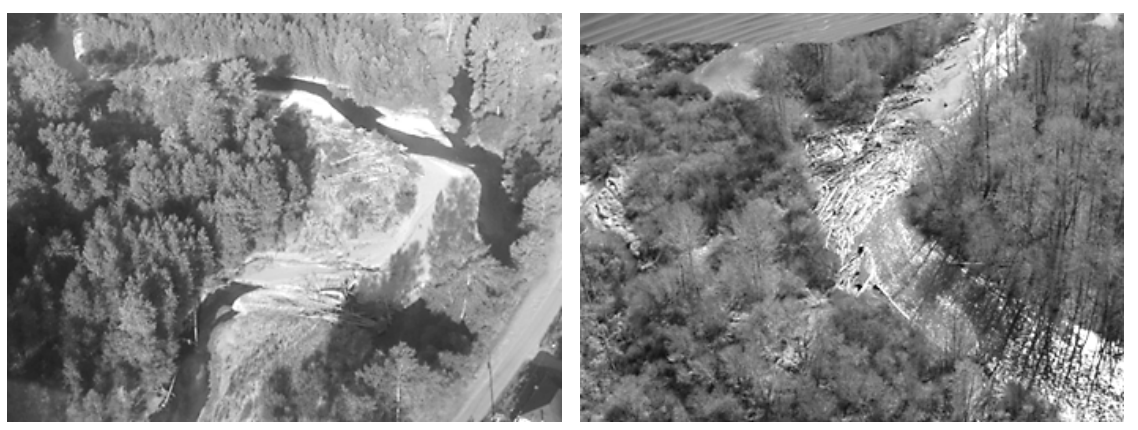

Figure 9: Bar deposition in zone of flow expansion.

\subsection{Sediment management}

An integrated flood management plan was developed in 2008-2009 in response to concerns about future flood risks in the region. The overall goal of the plan was to reduce flood risk to communities on the floodplain, while protecting aquatic and riparian habitat and addressing the cultural values of the rivers. The plan included a range of non-structural and structural mitigation measures, including promoting development of setback dikes as a long-term goal. Another component included an adaptive maintenance program to control log jams and sediment deposition that would incorporate habitat enhancement as part of the program. The aim was to maintain the design flood profile at approximate 2009 conditions in order to avoid having to continually raise and rebuild the dikes. Initial pilot gravel removals were made in 2010 and 2012. Planning for the work included geomorphic and biological studies to assess project effects and to define mitigation requirements to meet the "no net loss" habitat policy mandated under the federal Fisheries Act. The studies to date indicate that selective gravel removal on high exposed gravel bars, completed in concert with design-based 
mitigation strategies, can potentially improve habitat for salmonids. The improvements are related to the conversion of relatively lower habitat value gravel bar areas with a low ( 1:2 year flood) frequency of inundation to areas that are wetted over a wider range of flow conditions. Newly created habitat in gravel extraction zones is further enhanced with features that include large woody debris complexing, live willow staking and slope contouring. These features are designed to provide instream cover for salmon, maintain or improve nutrient sources for fish and maintain scour features in the alluvial substrates, which will provide deeper refuge pools and migration routes for salmonids.

The impacts on fish habitat in areas targeted for gravel extraction were examined from a quantitative and qualitative perspective (i.e., quantity and quality of habitat gained and lost). The analysis, currently underway, involves assessing the geospatial extent of ten key meso-habitat types at pre-, immediately post- and one year post-construction time intervals. To introduce a more qualitative value to the fish habitat evaluation, the areas of these ten key mesohabitats (at the specified pre- and post- construction intervals) are then multiplied by a subjective "Relative Habitat Rating" score to ascribe a Total Habitat Rating, which is used to ascertain whether the gravel work will result in a positive or negative impact to salmonid productivity (Figure 10).
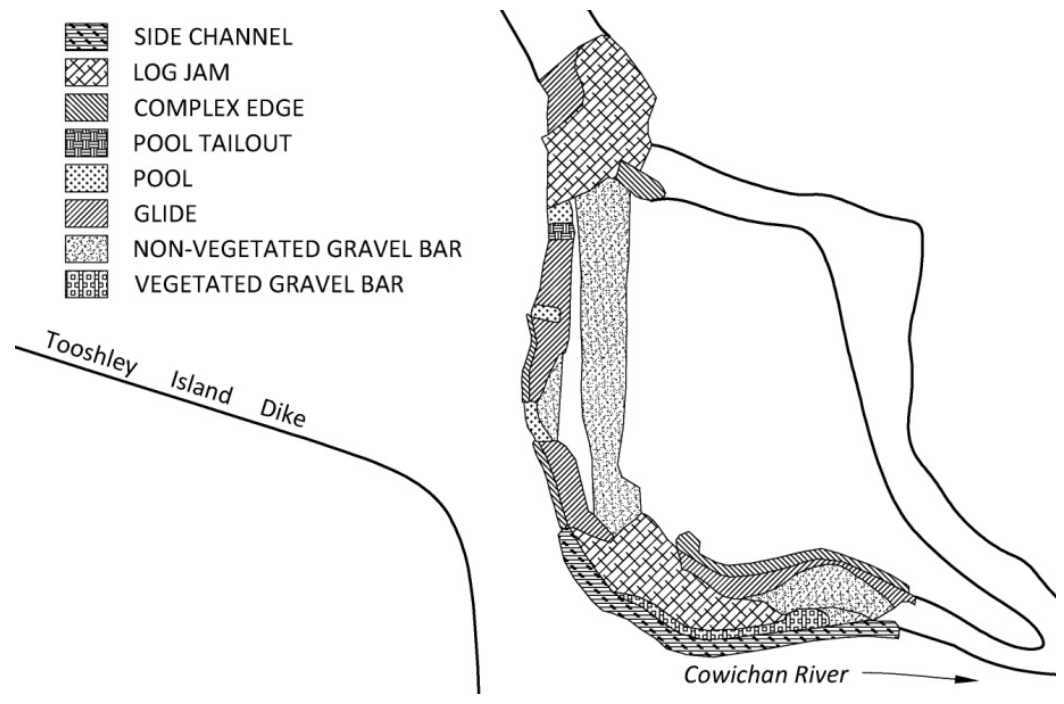

Figure 10: Habitat assessment on Cowichan River.

\subsection{Assessment of program on Cowichan River}

There is a general consensus that sediment management, including periodic gravel removal, will be necessary in order to ensure public safety from floods and erosion hazards. Realigning and stabilizing log jams can be used to reduce channel erosion and to provide important fish habitat features. Given the critical 
state of important species such as chinook salmon, there is a need to incorporate adequate mitigation measures into the removal plans.

\section{Discussion of results}

Removing gravel from alluvial rivers that are utilized by fish has been controversial in the past since in-stream excavations may induce upstream and downstream changes to the channel morphology, which alters aquatic habitat. The magnitude and extent of gravel removal effects depends mainly on the amount of material removed relative to the amount being transported into the channel reach as bed material load. Most studies on the effects of gravel removal on stream morphology have examined industrial scale gravel removals, where the sediment has been mined from the stream bed and the rate of extraction far exceeds the rate of supply (Kondolf [5]). In the case of sediment management on aggrading, confined river channels, the goal should be to maintain the design flood profile to avoid having to continually raise or rebuild dikes. In this situation the rate of gravel removal will be limited to approximate the long-term excess sediment supply so that neither degradation nor aggradation occurs (Figure 11).

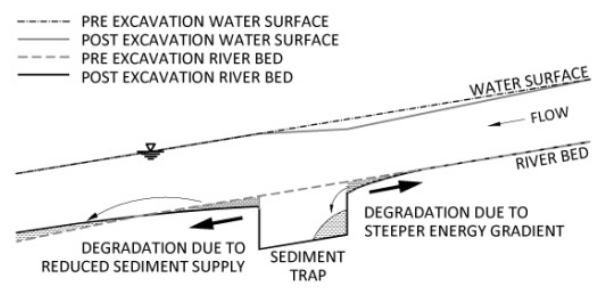

CASE 1: Excavation in a Uniform Channel

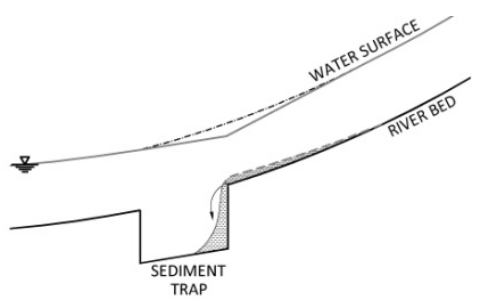

CASE 2: Excavation in an Aggrading Channel

Figure 11: Effect of sediment removals on stream profiles.

Sediment removal programs do not preclude other flood mitigation measures such as reducing the upstream sediment supply, constructing setback dikes or implementing land-use controls on the floodplain. In cases such as the Cowichan River, where there are multiple jurisdictions, including First Nations lands, it is not practical to restrict settlements from the floodplain. In this case, sediment management is an attractive option.

The usefulness of sediment removal can be judged by estimating the average bedload sedimentation rate in the reach $(S)$ :

$$
S=\frac{G_{b}}{\gamma_{s} A}
$$

where $\gamma_{s}$ is the dry bulk density of the sediment, $G_{b}$ is the excess bedload mass deposited in the reach and $A$ is the surface area of the active channel deposition zone in the reach. 
Table 2 shows sedimentation rates on the Vedder and Cowichan Rivers are much higher and will have a much greater effect on the flood profile than on the lower Fraser River, where sediment removal has been a significant management issue (Church [6]).

Table 2: $\quad$ Average sedimentation rate.

\begin{tabular}{|l|c|c|c|c|}
\hline Basin Features & Unit & Vedder & Cowichan & Fraser \\
\hline Bedload Deposition Rate & $\mathrm{m}^{3} \mathrm{yr}^{-1}$ & 50,000 & 15,000 & 250,000 \\
\hline Active Channel Width & $\mathrm{m}$ & 130 & 40 & 900 \\
\hline Sedimentation Index & $\mathrm{m}^{3} \mathrm{yr}^{-1}$ & 0.04 & 0.03 & 0.006 \\
\hline
\end{tabular}

Sediment removals can be carried out to maintain the flood profile while preserving fish habitat. The programs need to be implemented adaptively and should include monitoring, evaluation, plan updating and long-term implementation of the works. One of the first steps is to develop an adequate understanding of the sediment transport and deposition processes, particularly if sedimentation rates are changing over time. Preliminary pre-project estimates of gravel removal quantities can be determined using sediment budget methods. These estimates need to be revised and updated during implementation when more detailed information from project monitoring becomes available.

\section{Conclusions}

Sedimentation on confined alluvial fans and floodplains presents a significant challenge to long-term, sustainable flood management. Selective gravel removal on high exposed gravel bars, completed in concert with design-based mitigation strategies, can potentially improve habitat for salmonids.

\section{References}

[1] Martin, Y. and Church, M., Bed-Material Transport Estimated from Channel Surveys, Vedder River, BC. Earth Surf. Processes and Landforms, Vol. 26, John Wiley \& Sons, 1995.

[2] Ham, D.G. and Church, M., Bed-Material Transport Estimated from Channel Morphodynamics, Chilliwack River, BC. Earth Surf. Processes and Landforms, Vol. 25, John Wiley \& Sons, 2000.

[3] Bergman, L.A., Vedder River Gravel Management Plan, BC Environment, Water Management, Vancouver, 1996.

[4] Nova Pacific Environmental, 2008 Vedder River Gravel Excavation Habitat Changes and Environmental Impacts, May 2010.

[5] Kondolf, G. M., Managing Bedload Sediment in Regulated Rivers: Examples from California, USA, Geophysical Monograph \#89, AGU, 1995. Church, M., River Science and Fraser River: Who Controls the River? In Gravel Bed Rivers V, ed. M. Paul Mosley, New Zealand Hydrological Society, pp. 607-632, 2001. 